\title{
The Usage of Non-Wood Forest Products - Culinary and Artisanal Traditions in Romania
}

\author{
Lucian Dincă $^{1}$ \& Voichița Timiș-Gânsac ${ }^{2}$ \\ ${ }^{1}$ Marin Drăcea" National Institute for Research and Development in Forestry (INCDS), 13 Cloșca Street, Brașov- \\ 500040, Romania \\ ${ }^{2}$ University of Oradea, Faculty of Environmental Protection, Oradea, Romania \\ Correspondence: Voichița Timiș-Gânsac, University of Oradea, Faculty of Environmental Protection, Oradea, \\ Romania. Tel: 40-745-678-316. E-mail: timisvoichita@yahoo.com
}

Received: April 1, 2020 Accepted: April 16, 2020 Online Published: May 5, 2020

\begin{abstract}
Non-wood forest products are essential for numerous industrial branches, as well as for the creation of culinary and artisanal products. From this point of view, Romania has numerous such products. The present article succinctly describes ten products resulted from the local usage of some non-wood forest products: porcini soup in Bucovina (Porcinis mushrooms -Boletus edulis-); hârzobi in Neamt (trout fish-Salmo trutta fario); common beech trout in Covasna (Pleurotus ostreatus mushrooms); truffles-Tuber sp.- zacusca (stew) in Bucharest; holopchi with porridge and porcini or honey mushrooms in Moisei; fir bellows cheese in Bran Moeciu; brandy from bird cherry fruits (Prunus avium) in Brad; tinder mushroom (Inonotus obliquus) in Harghita; fir's needles for dead wreaths in Sibiu; rattle, rich snowdrop flowers, dried crocus flowers, roots and bark (privet bark, black alder bark, buckthorn bark) in Botiza. Knowing and promoting (creating local brands) these products is extremely important.
\end{abstract}

Keywords: non-wood forest products, traditional products, culinary usages, artisanal products

\section{Introduction}

Non-wood forest products comprise products that are used as food or nutriments (nuts, mushrooms, fruits, medicinal and aromatic plants), fibres (used in construction, furniture industry etc.), resin, latex or diverse animal or vegetal products used in medicinal and cosmetics purposes, as well as other afforested fields and trees situated outside forests (FAO, 2001). FAO places a special emphasis on non-wood forest products, proven by the establishment of a dedicated program entitles "Promoting and developing non-wood forest products". This program serves as a centre for knowledge exchange in order to improve the usage of non-wood forest products.

Romania has a multitude of traditional culinary products, the main advantage being represented by the cooking methods and old traditions kept from the most ancient times. The products are offered in many fairs and cultural events in order to attract numerous visitors by combining entertainment with food and cultural education (Cohen et al., 2004; Salanță et al., 2015).

Romanian cuisine is unique through the fact that each corner of the country is a different gate but equally tastefully. Gastronomy feasts, organized by small communities, have started to temporarily attract large groups of Romanian and foreign tourists (Boită et al., 2015; Muntean et al., 2010; Nistoreanu et al., 2013). Even from the ancient times, the populations that have inhabited Romania were highly interested in the culinary art, a fact proven by the existence of information that date back to the Dacian (Baltescu, 2016; Tomescu et al., 2014). Each of Romania's historical region has a well-defined historical, socio-cultural, economic and gastronomic identity (Smaranda, 2017). Furthermore, the usage of certain ingredients and specific cooking methods were transmitted from one generation to another and are known nowadays under the name of "traditional food". Traditional food played a major role in the traditions of different cultures and regions for over thousands of years. They include products that were consumed locally and regionally for a long period of time.

The preset paper highlights some of the most important and specific products in the Romanian cuisine and artisanal industry derived from non-wood products.

\section{Method}

Defining and classifying non-wood forest products were obtained through the results of the European COST Action FP 1203 "European non-wood forest products network" cooperation action (www.nwfps.eu). Within this action 
that has lasted four years, specialists from the majority of European countries have analysed non-wood forest products from all their perspectives, including their usage.

Data concerning the analysed traditional products were taken from the speciality literature and from the internet, while the quantities of harvested products (per years and regions) were taken from the data mentioned in forest management plans and statistical forest situations. Data was collected for each administrative forestry unit and for their main non-wood forest products. As such, data from the last 10 years was analyzed, followed by an average of the annual production (the production varies for some non-wood products based on the climatic factors). The data was then centralized for each County and for the entire country.

\section{Results}

The main non-wood forest products from Romania as well as their distribution areas are rendered in Table number 1.

Table 1. Non-wood forest products in Romania used in culinary and artisanal purposes

\begin{tabular}{|c|c|c|c|}
\hline \multicolumn{2}{|c|}{ Non-wood forest products } & \multirow[t]{2}{*}{ Distribution in Romania } & \multirow[t]{2}{*}{ Usage } \\
\hline Category & Species & & \\
\hline \multirow[t]{5}{*}{ Mushrooms } & Boletus edulis & Resinous and broadleaved species & Soup, stew. \\
\hline & Pleurotus ostreatus & Beech trees & Stew, pickles \\
\hline & Tuber sp. & Trees from hills and plains & Food spice \\
\hline & Armillaria sp. & Beech forests & Zacusca, stew, holopchi \\
\hline & Inonotus obliquus & Hill and plain broad-leaves & Artisanal products \\
\hline \multirow[t]{5}{*}{ Tree products } & Picea abies bark & Carpathian's forests & Cheese \\
\hline & Abies alba needles & Carpathian's forests & Dead wreaths \\
\hline & Prunus avium fruits & $\begin{array}{l}\text { Forests from the hill and mountain } \\
\text { areas }\end{array}$ & Brandy, jam, syrups \\
\hline & Pyrus pyraster fruits & Forests from the hill and plain areas & Jam, brandy \\
\hline & $\begin{array}{l}\text { Malus sylvestris } \\
\text { fruits }\end{array}$ & Forests from the hill and pain areas & Jam, comfiture \\
\hline \multirow{3}{*}{$\begin{array}{l}\text { Under-story } \\
\text { plants }\end{array}$} & Rhamnus frangula & River shores, clearings, groves & Carpets \\
\hline & Allium ursinum & Beech forests & Soup, medicinal \\
\hline & Sambucus nigra & From hill to inferior mountains & Jam, comfiture \\
\hline \multirow[t]{2}{*}{ Animal origin } & Salmo trutta fario & Mountain rivers & Hârzobi \\
\hline & Honey & All over the country & $\begin{array}{l}\text { Culinary,medicinal } \\
\text { purposes }\end{array}$ \\
\hline
\end{tabular}

\section{Bucovina Porcino Soup}

Porcinis (Boletus edulis L.) are comestible forest mushrooms that belong to the spontaneous flora and are recognizable through their intense, sweet taste. Their smell resembles fruits, while their texture is fleshy, hard, consistent and compact. Porcinis are full of minerals and vitamins (iron, calcium, sodium, phosphorus) and vitamins (A, C, D, K, B6), while they lack sugar and lipids.

Porcini is considered one of the oldest hat mushrooms, being appreciated for its exceptional culinary qualities, ranking second after truffles (Bagnasco et al., 2015; Cui et al., 2016; Kuès, et al., 2000). Besides its culinary qualities, the species also presents a therapeutical interest. During 2009-2015 Romania has recorded an average annual quantity of harvested edible mushrooms of 636 tonnes (Vasile et al., 2017). Boletus is the most valuable mushroom and NWFP species in many areas of the country (Enescu et al., 2018; Timiş-Gânsac et al., 2018). 


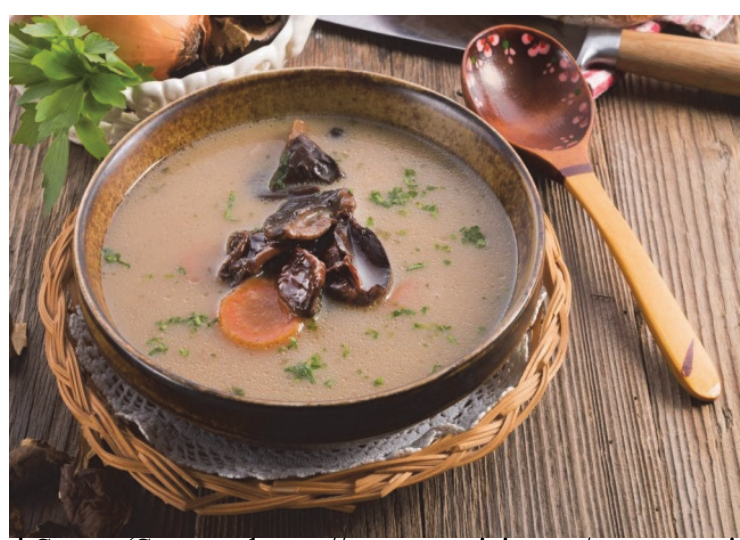

Figure 1. Dry Porcini Soup. (Source: https://www.ecuisine.ro/uncategorized/bors-de-hribi/)

\section{Neamt "Hârzobi"}

Trout (Salmo trutta fario) is a fish species that lives mostly in mountain waters or waters with a relatively low temperatures during summer, but can also be found in lower, sub mountainous and hill areas with the condition that the water is highly oxygenated. Renowned for its tasteful, tender meat, it becomes a delicacy through smoking.

The hârzob fish is by far one of the area's most well-known and appreciated culinary delicacies, being appreciated both by tourists and locals.

The unique taste and aroma are achieved through its cooking method: the trout is prepared at a warm fire, first from common beech wood, then from cherry, while its final aroma is offered by the fir ־cobza“. For a long time, they were known as vârzobi, originating from hârzobi or hârzoabe - ustensils used by hunters in areas hard to reach because of snows. Their shape was oval, being realized from resistant wood.

In order to obtain a hârzob, the locust rods are shaped as a tennis racquet by using braids from a more resistant thread. The fir needles is placed on one such palettes pair and it offers an exceptional aroma to the smoked fish. Furthermore, this technique allows for a longer conservation time, as the smell banishes insects and the hârzob can be kept for a lengthier timeframe.
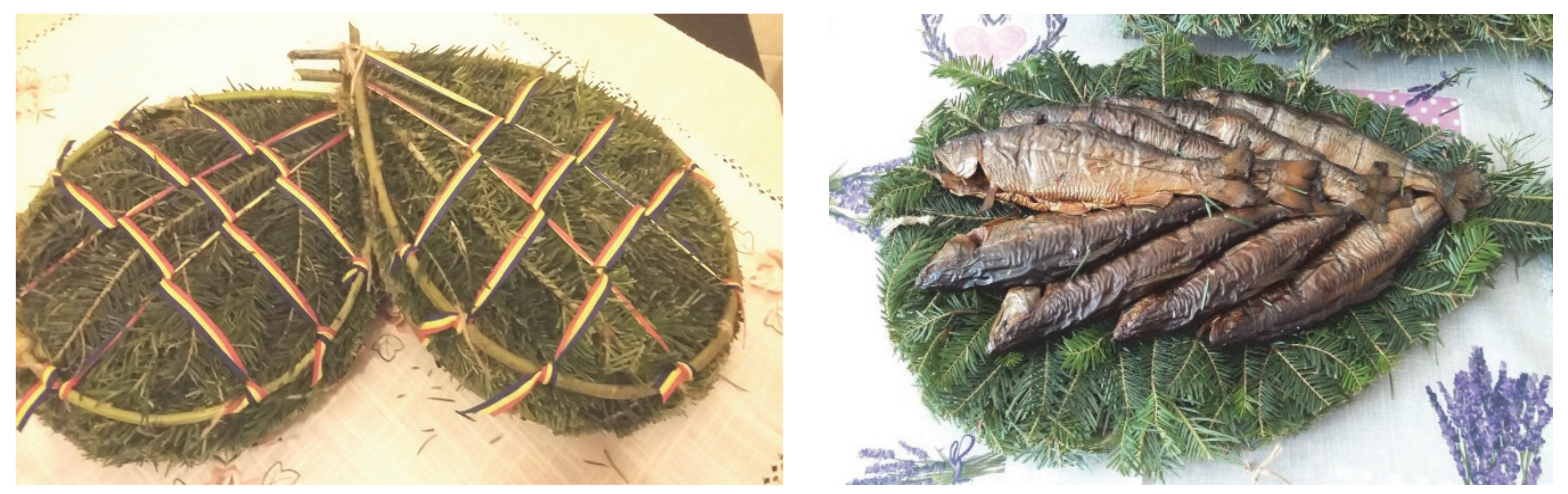

Figure 2. Hârzob Trout. Source: original (photo Timiș V.)

\section{Common Beech trout farms pickles from Covasna}

Common beech trout (Pleurotus ostreatus (Jacq.ex.Fr..) is a comestible lignicolous mushroom found on common beech (Fagus sylvatica L.) and other broad-leaved species such as: oak (Quercus robur L.), hornbeam (Carpinus betulus L.), birch (Betula pendula Roth.), linden (Tilia cordata Mill.), common elder (Sambucus nigra L.), buckeye (Aesculus hippocastanum L.), walnut (Juglans regia L.), mulberry (Morus alba L.). It can also be found rarely on resinous species. The species is highly appreciated for its nutritive value, proven by its increased mass cultivation. Due to their unique taste, Pleurotus mushrooms are the ideal solution for a delicious stew. Furthermore, these mushrooms are good as autumn pickles, so as to be kept and savoured during a cold winter day. In Covasna area, the locals know the forest areas (trees) where these mushrooms are growing, they harvest them during autumn and prepare them as delicious pickles. 


\section{Bucharest truffle "zacusca" (stew)}

Romania is a country extremely rich in truffles (Tuber sp.), the most harvested species being Tuber aestivum Vittadini and Tuber magnatum Pico ( Dincă et al., 2014; Dincă et al., 2015).Truffles are renowned as seasoning added in different types of dishes, while their long-term conservation is rather difficult (Dincă et al., 2012). A producer from Bucharest has realized a truffle stew that became highly sought after in Romania and especially abroad. This product is new and will be homologated.

\section{Moisei holopchi with porridge and porcini or honey mushrooms}

"Sarmalele" (holopchi) (traditional Romanian food with origins disputed between Turkey/Greece/Romania) are a mixture of rice and meat covered in cabbage leaves. In Maramureș however, porridge, porcini or honey mushrooms are also used in their preparation. The above-mentioned mushroom species are harvested in large quantities in this area (an average of 57.4 Armillaria spp. and 45.1 Boletus spp. tones were harvested during 2005-2013, ( Enescu et al., 2012).

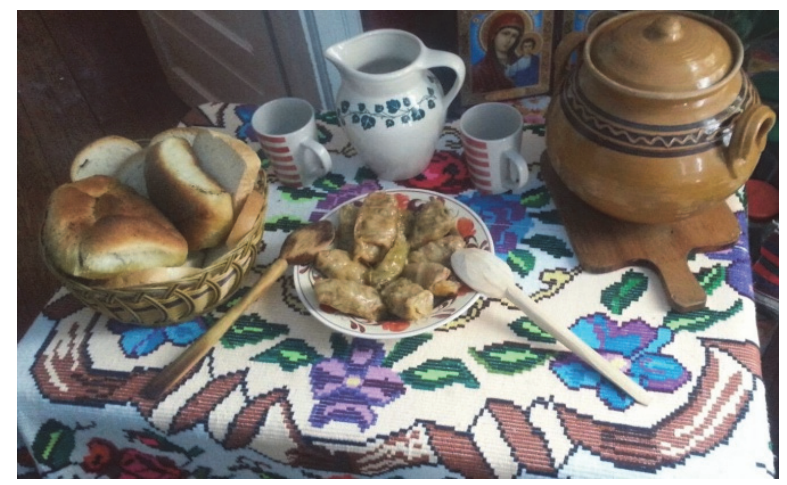

Figure 3. Holopchi with porridge and porcini. Source: original (photo Timiș V.)

Honey mushrooms (Armillaria mellea (Vahl) P.Kumm.) grow in broad-leaved and resinous forests, on hill and mountain plains, but can also be found on plains. They are harvested in large quantities, being used during winter as aperitifs or garnish. The usage of honey mushrooms by the local populations from even the oldest times is proven by the numerous cities from all around Romania that use the mushroom (gheba) in their (Birkinshaw et al., 1948; Dincă et al., 2010).

\section{Bran-Moeciu fir bellows cheese}

Bellows cheese, especially the one originating in Bran, is one of Romania's culinary specialities, being prepared traditionally in mountain sheep yards. It is a traditional product, maybe even the oldest type of cheese produced in Romania. The fir bark in which the cheese is places is obtained from firs that are 20-25 years old.

Fir bellows cheese is a type of cheese prepared by peasants from Bran area and Braşov's surroundings. Its rustic aspect, taste and flavour are exceptional and explains its success on the national market and at international profile exhibitions.
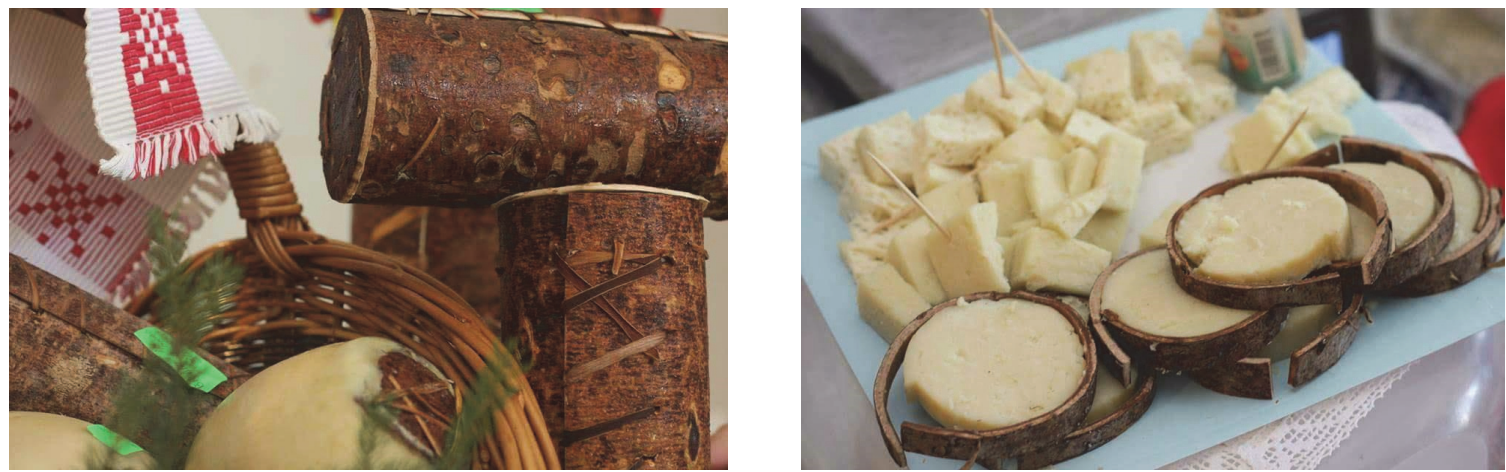

Figure 4. Fir bellows cheese. Source: original (photo Timiș V.) 


\section{Brandy from bird cherry fruits (Prunus avium L.), Brad, Hunedoara}

"Țuica" (brandy) is an alcoholic beverage obtained through the distillation of fermented fruits, especially prunes. The name "țuica" is found only in Romania, so it can be considered an autochthonous product. It has an alcohol content of 24 up to $50 \%$ volume and is obtained from different local prune populations. The best brandies however are obtained from cherries harvested from wild nongrafted cherry trees. Fruits represent a major resource in Romania's sub Carpathian region. As such, prunes were evaluated for their utility in generating jam, dry fruits and brandy. This last product ("țuică") still holds a considerable commercial market, regardless of the competition posed by urban distilleries and imported drinks (Muica, 1996).

Wild cherry (bird cherry, sweet cherry (Prunus avium L.) is one of the precious (noble) broad-leaved species for which a special interest exists in Romania (Dincă, 2003). As such, it is a valuable mixture species on plain forests and Quercus Carpathian stands from West, Central and North-East Romania. Bitter cherries have different types of usages, both in the alimentary industry, as well as in the medicinal one. For example, they are transformed in natural juices, syrups, stews, marmalade, comfiture or liquor. The most appreciated product obtained from bitter cherries is brandy.

\section{Tinder artisanal products from Harghita}

Tinder (Inonotus obliquus L.) is a lignicolous, sometimes saprophyte and always parasite mushroom that grows on many types of trees: common beech (Fagus sylvatica L.), Turkey oak (Quercus cerris L.), holm (Quercus petraea (Matt) Liebl. and sporadically on Occidental Sycamore (Platanus occidentalis L.).

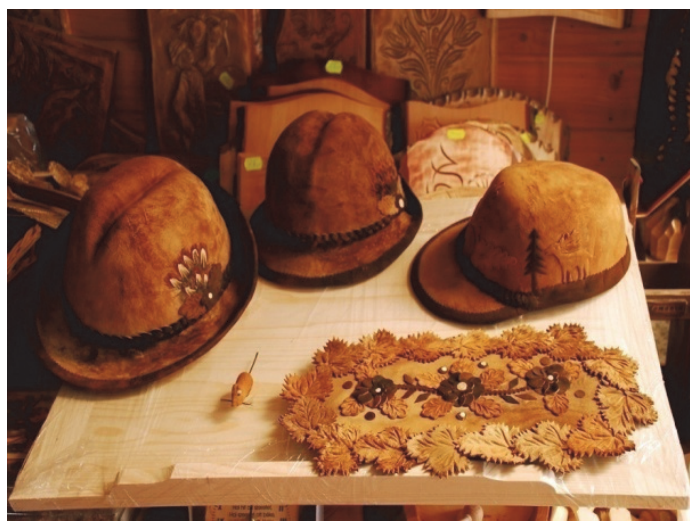

Figure 6. Tinder artisanal products

(Source: https://www.google.ro/search?q=produse+artizanale+din+iasca)

The usages of this mushrooms are multiple, from igniting and maintaining fire to garments, easy to snuff tobacco, drying flies for fly fishing etc. Besides these therapeutically usages, the species is used for obtaining artisanal products. Common beech or birch tinder mushroom is cleaned of its crust and splintered into slices.

The slices are then elongated, with a wood hammer if needed, until the wanted shape is obtained. After manufacturing, tinder is used for making hats, caps, purses, bracelets and all kinds of decorative objects or materials for cleaning eyeglasses.

\section{Dead wreaths from Sibiu}

During winter, the fir's needles are issuing a high quantity of aromatic oils that possess exceptional curing effects. In popular medicine and gastronomy, this product is used for tea, tincture, kvass and beer. Furthermore, it can be used as a spice for second courses and salads. In Romanian regions populated by Germans, an old tradition exists for realizing wreaths for the dead from resinous needles.

Carpets dyed with rattle, rich snowdrop flowers, dried crocus flowers, roots and bark (privet bark, black alder bark, buckthorn bark) from Botiza, Maramureș County.

Old dyeing traditions relying on the exclusive use of plants and traditional motivs are still kept in Botiza, Maramureş County (Łuczaj et al., 2015). A special technique that is important to acknowledge is the dyeing of threads that are then used for sewing and weaving. From the oldest times, Romanian women have used vegetal dyes for obtaining their intended nuances. 


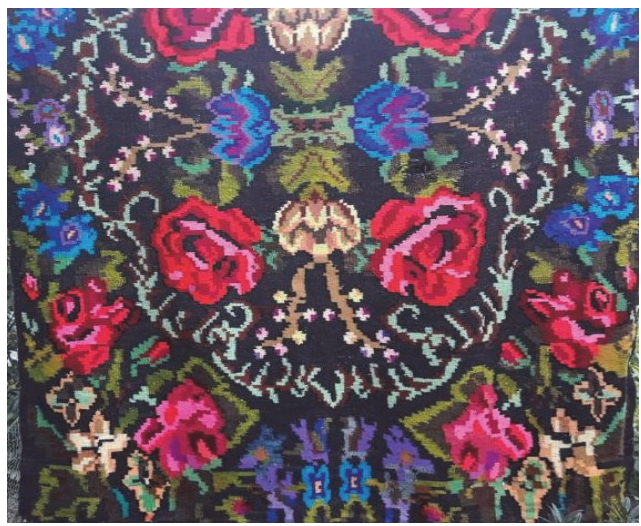

Figure 7. Carpet dyed in vegetal colors, Moisei, Maramureş. Source: original (photo Timiş V.)

The most used colors were obtained from: black alder bark (Alnus glutinosa (L.) Gaertn.), oregano (Origanum vulgare L.), common walnut leaves (Juglans regia L.), birch (Betula pendula L.), mulberry (Morus sp.), green nut shells (Juglans regia L.), onion (Allium cepa), rattle flowers (Hypericum perforatum), Amaranthus ssp. (Dincă et al., 2018), rich snowdrop (Leucojum vernum) or crocus (Colchinum ssp.). The deying techniques, even though very old, are still kept today even though its usage areal is much more reduced. Buckthorn (Rhamnus frangula $\mathrm{L}$.) is a shrub that grows in humid areas, in clearances and was used from antiquity for dyeing cotton, flax and fleece.

The buckthorn bark is shiny, yellow-brown in the interior and brown-grey in the exterior and presents small white, stark spots. Buckthorn bark is one of the NWFPs harvested in high quantity in Romania (Vasile et al., 2015).

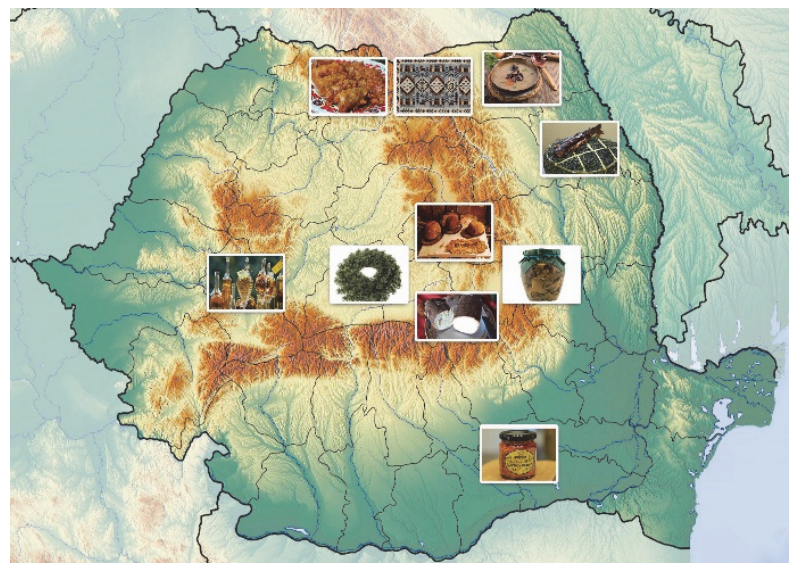

Figure 8. Traditional products obtained from non-wood forest products in Romania (Source: original)

\section{Conclusions}

Numerous areas from Romania (Bucovina, Maramureș, Transylvania) are renowned for their traditional products, some of them being obtained by manufacturing non-wood forest products (figure 8). Many non-wood products have culinary usages. Amongst the traditional products present in different regions of our country, the present article has mentioned the following: porcino soup in Bucovina (Porcinis mushrooms -Boletus edulis); hârzobi in Neamt (trout fish- Salmo trutta fario); common beech trout in Covasna (Pleurotus ostreatus mushrooms); truffles -Tuber sp.- zacusca in Bucharest; holopchi with porridge and porcini or honey mushrooms in Moisei; fir bellows cheese in Bran Moeciu. This was completed by different drinks, such as brandy from bird cherry fruits -Prunus avium- in Brad. Other non-wood forest products were used over time in artisanal products, such as: tinder mushroom (Inonotus obliquus) for hats, caps, purses, bracelets and all kinds of decorative objects in Harghita; fir's needles for dead wreaths in Sibiu; or rattle, rich snowdrop flowers, dried crocus flowers, roots and bark (privet bark, black alder bark, buckthorn bark) for carpets in Botiza. Knowing, understanding and perpetuating these traditions is extremely important for maintaining and promoting the cultural, ethnic, culinary or artisanal Romanian patrimony. 


\section{References}

Baltescu, C. A. (2016). Culinary experiences as a key tourism attraction. Case Study: Brasov County. Bulletin of the Transilvania University of Brasov. Economic Sciences. Series V, 9(2), 107.

Birkinshaw, J. H., Stickings, C. E., \& Tessier, P. (1948). Biochemistry of the wood-rotting fungi: 5. The production of d-threitol (1-erythritol) by Armillaria mellea (Vahl) Quélet. Biochemical Journal, 42(3), 329. https://doi.org/10.1042/bj0420329

Boiță, P. L. M., \& Costi, P. L. B. (2014). Gastronomic tourism management revitalizer factor of the tourism offer. Academica Brâncusi Publisher-Economy Series, Special Issue Information Society and Sustainable Development, 398-401.

Cohen, E., \& Avieli, N. (2004). Food in tourism: Attraction and impediment. Annals of tourism Research, 31(4), 755-778. https://doi.org/10.1016/j.annals.2004.02.003

Cui, Y. Y., Feng, B., Wu, G., Xu, J., \& Yang, Z. L. (2016). Porcini mushrooms (Boletus sect. Boletus) from China. Fungal Diversity, 81(1), 189-212. https://doi.org/10.1007/s13225-015-0336-7

Dincă, L., \& Dincă, M. (2014). Consideraţii privind realizarea de plantaţii trufiere. Revista de Silvicultură și Cinegetică, 19(34), 109-114.

Dincă, M., \& Dincă, L.C. (2015). Truffles and soil. Research Journal of Agricultural Science, 47(3), 44-50.

Dincă, M., \& Dincă, L. (2012). Recoltarea trufelor. Revista de Silvicultură şi Cinegetică, 30, 117-121.

Dincă, L., Enescu, C.M., Dincă, M., \& Cântar I.C. (2016). Mushrooms in Romanian toponymy, vocabulary and literature. Journal of Horticulture, Forestry and Biotechnology, 20(3), 119- 125.

Dincă, L., \& Dincă, M. (2003). Considerations regarding the valuable broadleaved species in Romania. Analele ICAS, 46(1), 315-320.

Enescu, C. M., Dincă, L., \& Vasile, D. (2017). Importance of non-wood forest products for Maramureș County. Revista de Silvicultură și Cinegetică, 40, 92-97.

Enescu, C.M., Dincă, L., \& Cântar, I. (2018). Which are the most common non-wood forest products in Timis County? Research Journal of Agricultural Science, 50(1), 51-56.

FAO. (1999). Towards a harmonized definition of non-wood forest products. Unasylva, 50(198), 63-64.

Kuès, U., \& Liu, Y. (2000). Fruiting body production in basidiomycetes. Microbiology and Biotechnology, 54(2), 141-152. https://doi.org/10.1007/s002530000396

Łuczaj, Ł., Stawarczyk, K., Kosiek T., Pietras M., \& Kujawa A. (2015). Wild food plants and fungi used by Ukrainians in the western part of the Maramureş region in Romania. Acta Societatis Botanicorum Poloniae 84(3), 339-346. https://doi.org/10.5586/asbp.2015.029

Muica, N., \& Turnock, D. (1996). The potential for traditional food and drink products in Eastern Europe: Fruit processing - especially brandy ("tuica") distilling - in Romania. GeoJournal, 38(2), 197-206. https://doi.org/10.1007/BF00186670

Muntean, C. M., Nistor, C., Nistor, R., \& Sarpe, D. (2010). Oeno-gourmet tourism - a new way of Romanian tourism boost. Latest Trends on Cultural Heritage and Tourism, 241-246.

Nistoreanu, P., Dorobantu, R. M., \& Gheorghe, G. (2013). Traditional cuisine, a major factor to help promote Romanian sustainable tourism. Polish Journal of Commodity Science, 3, 24-31.

Salanţă, C. L., Păucean, A., Tofană, M., Man, S., \& Pop, C. (2015). Romanian Cuisine: Culinary Habits and Local Produce. Journal of Agroalimentary Processes and Technologies, 21(2), 186-191.

Smaranda, S. (2017). Traditional Romanian food-as the result of history, nature, way of life and human ingenuity. Lucrări Științifice Management Agricol, Seria I, 19(1), 229-235.

Tomescu, M. A., \& Botezat, A. E. (2014). Culinary tourism in Romania - professional points of view. Faculty of Tourism and Hospitality Management in Opatija. Biennial International Congress. Tourism \& Hospitality Industry, pp 677-688.

Timiș-Gânsac, V., Enescu, C.M., Dincă, L., \& Oneț, A (2018). The management of non-wood forest products in Bihor County. Natural Resources and Soustainable Development, 8(1), 27-34. https://doi.org/10.31924/nrsd.v8i1.004

Vasile, D., Dincă, L., \& Enescu, M.C. (2017). Impact of collecting mushrooms from the spontaneous flora on 
forest ecosystems in Romania. AgroLife Scientific Journal, 6(1), 268-275.

Vasile, D., Dincă, L., \& Voiculescu, I. (2015). Collecting medicinal plants from spontaneous flora of forest fund managed by National Forest Administration Romsilva. Revista de Silvicultură și Cinegetică, 20(37), 88-94.

\section{Copyrights}

Copyright for this article is retained by the author(s), with first publication rights granted to the journal.

This is an open-access article distributed under the terms and conditions of the Creative Commons Attribution license (http://creativecommons.org/licenses/by/4.0/). 